\title{
The Effects of Two Pre-task Activities on Improvement of Iranian EFL Learners' Listening Comprehension
}

\author{
Farahman Farrokhi \\ English Department, Faculty of Persian Literature and Foreign Languages, Tabriz University, Tabriz, Iran \\ Email: ffarrokhi20@yahoo.co.uk \\ Vahideh Modarres (Corresponding author) \\ English Department, Faculty of Persian Literature and Foreign Languages, Tabriz University, Tabriz, Iran \\ Email: v-modarres@live.com
}

\begin{abstract}
The present study attempted to find out the extent to which two pre-task activities of "glossary of unknown vocabulary items" and "content related support" assisted EFL language learners with their performance on listening comprehension questions across low proficiency (LP) and high proficiency (HP) levels. Each level consisted of three groups, two experimental groups and one control group (twenty participants in each group). One experimental group received "glossary of unknown vocabulary items" with the pronunciations while the other group received content related support (in written form) with the aim of activating prior knowledge before administering post-lecture listening comprehension questions. The statistical analysis of the data revealed that in low proficiency level, vocabulary group outperformed both content and control groups while in high proficiency level, content group outperformed the other groups. The study concluded by suggesting that pre-task activities need to be used taking account of the support type and the learners' proficiency level.
\end{abstract}

Index Terms-listening comprehension, pre-task activities, glossary of unknown vocabulary items, content related support, prior knowledge, proficiency level

\section{INTRODUCTION}

Changes in the stream of language teaching reflect the direction of moves towards oral proficiency rather than reading comprehension by the time passed. A great number of studies have examined the effect of providing background knowledge to help learners enhance listening comprehension (Keshavarz \& Babai, 2001; Long, 1989; Markham \& Latham, 1987). On accounting of the entire challenges EFL learners encounter in classrooms due to the listening complexity, some pre-listening activities as supports in the procedure of teaching listening are proposed by authors (Chastain, 1988; Richards, 1990; Rost, 2001; Underwood, 1989; Ur, 1984).

\section{LITERATURE REVIEW}

Communication contains two conversion processes of creating a meaningful message and recreating that message. To recreate the message from spoken language, it is needed for learner to have some shared linguistic knowledge with the speaker (Chastain, 1988). Anderson and Lynch (1988) have defined, "listening as the means to immediate oral production" (p. 64). Brown (1980) maintains, "Listening ability lies at the heart of all growth, from birth through the years of formal education. The better those learning skills are developed, the more productive our learning efforts" ( $p$. 10). So, this skill is one of the crucial equipments by which listener attempts to learn a second language.

As Rost (1990) has noted, "It is now well established that there is not a direct correspondence between the articulatory, acoustic, and auditory dimensions of spoken language" (p. 33). He adds, "Meaning is created only by an active listening in which the linguistic form triggers interpretation within the listener's background in relation to the listener's purpose" (Rost, 1990, p. 62). Also he has referred to the inferential processes while listening such as estimating the sense of lexical references, constructing propositional meaning, assigning meaning to the discourse, supplying underlying links to the discourse, and assuming an intention for the speaker's utterance. According to the multidimensionality of listening skill explained, it is regarded as a demanding process, not only because of the complexity of the process itself, but also due to factors that characterize the listener, the speaker, the content of the message, and any visual support that accompanies the message (Brown \& Yule, 1983).

Due to complexity of this skill especially in real-like situations, learners have always had difficulties in completing listening tasks. Buck (2001, as cited in Chang \& Read, 2008) identifies numerous difficulties which can be confronted in listening tasks such as unknown vocabularies, unfamiliar topics, fast speech rate, and unfamiliar accents. A 
considerable number of difficulties learners face in listening comprehension are discussed in literature (DonaldsonEvans, 1981; Underwood, 1989; Ur, 1984). All these facts lead to the idea that to make students successful listeners, the teacher must support the learners according to their needs, goals, and situation in which they perform. To reach some optimal degree of comprehension, pre-task activities providing background knowledge, linguistically and nonlinguistically, have been demonstrated to be helpful in performing different activities (Richards, 1990; Rost, 1990).

\section{A. Listening Materials and Activities}

Morley (1991) has explained that in developing listening materials and activities, the following three important features of listening need to be taken into account: (1) Listening is an act of information processing which involves the listeners in various communicative modes; (2) Broadly speaking, real-world spoken communication serves two linguistic functions: an interactional and transactional functions, and (3) The cognitive processing of spoken language involves simultaneously activation of both top-down and bottom-up processes to construct the intended meaning. Richards (1983) has classified the various types of listening activities from different aspects. He has discussed that the material can be in the form of a monologue or a dialogue. They can be delivered by a native speaker or non-native speaker.

Ur (1984) believes that in order for benefiting from listening tasks, it is necessary to develop this skill in a direct and systematic way. To reach this goal, teaching listening has been suggested to include pre-task period. The period prior to act on listening task, pre-listening phase, is associated to preparation stage in which learners are provided by some activities as a kind of support to help them act on task. For Rost (2001), listening tasks "involve explicit 'pre-listening' steps, some activities that the learner does prior to listening to the main input in order to increase readiness" (p. 20).

Chastain (1988) has argued that pre-listening activities can be considered as the most crucial aspects in listening process because other activities depend on the extent to which the teacher has been successful in activating students' background and directing them to reach the goals of activity. Underwood (1989) has listed pre-task activities as: discussion about the topic, looking at pictures, list of items, guiding questions, reading a text, predicting, making list of possibilities. So, the aim for providing pre-listening activities is to activate pre-existing knowledge embedded in learner's mind. Widdowson (1983) has highlighted three sources a listener utilizes in the process of comprehension. He has referred to them as (a) systemic and linguistic knowledge (knowledge of phonological, syntactical, and semantic components of the language system) (b) contextual knowledge (knowledge of situation and co-text) and (c) schematic or background knowledge (factual, socio-cultural and procedural knowledge).

\section{B. Schema Theory and Background Knowledge}

Prior knowledge in listener's mind entails the contribution of schematic knowledge when performing on listening tasks. Edwards and McDonald (1993) hold that "schema theory details how people store and use knowledge about a domain" (p.60). Yule (2006) has maintained that "a schema is a general term for a conventional knowledge structure that exists in memory" (p. 132). Generally, schematic knowledge refers to the socio-cultural background knowledge. Edwards and McDonald (1993) maintain, "Schema theory suggests that knowledge level is a much more important predicator of listening than are other variables" (p. 72). Taylor and Crocker (1981) have noted:

A schema is a cognitive structure that consists in part of the representation of some defined stimulus domain. The schema contains general knowledge about that domain, including a specification of the relationships among its attributes, as well as specific examples or instances of the stimulus domain. (p. 91)

Schmidt-Rinehart (1994) carried out a research to find out whether there was an interaction between topic familiarity and listening comprehension. The results revealed that all of the students in different levels outscored in listening task of familiar topic. Also, Chiang and Dunkle (1992) investigated the effect of speech modification, prior knowledge, and listening proficiency on EFL listening comprehension. The Chinese EFL students' listening comprehension was measured over listening to a lecture. The students were required to answer a multiple-choice test which contained both passage-dependent and passage-independent items. The results indicated that the students outperformed on familiartopic lecture than on unfamiliar-topic lecture.

Weissenreider (1987) tested intermediate and advanced learner's comprehension of Spanish-language newscast over the role of textual and content schema. News casting materials were highly specialized texts, in economic register. The materials were supposed to be familiar in topic to students. Knowledge of the organizational structure of the materials (textual schema) and knowledge about the content of materials (content schema), helped comprehension of new data, especially when combined with some listening strategies such as identifying key semantic elements, hypothesizing associations, anticipating related issues.

In addition to the effect of background knowledge prior to listening test, Widdowson (1983) has stated that vocabulary provision can compensate for the lack of linguistic knowledge. Among difficulties numerated above, lack of vocabulary knowledge can be considered one of the most important one. Lexico-grammatical knowledge is considered to allow L2 learners to derive literal meaning of the message which facilitates listening (Mecartty, 2000). Some authors believe that lack of vocabulary is one of the primary causes which exacerbated listening difficulties (Goh, 2000; Kelly, 1991; Rost, 1990).

Vandergrift (2003) indicated that "less-skilled listeners tended to segment what they heard on a word-by-word basis, using almost exclusively a bottom-up approach" (p. 467). Osada (2001) investigated low-proficient learners to see 
whether they preferred using bottom-down procedure or top-down procedure. The result of the study showed that EFL low-proficient learners tended to rely on bottom-up processing. Also, Vandergrift (2003) studied less-skilled and moreskilled learners' way of using different strategies. He concluded that less-skilled learners used word-by-word method of translating a text paying little attention to connection of ideas between the text segments. Therefore, the less-skilled learners acted mainly on bottom-up procedure.

Despite the fact that lack of vocabulary knowledge seems to cause the most worry of EFL learners, there are few studies regarding the effect of vocabulary preparation on listening comprehension (Chang, 2006; Chang \& Read, 2008; Lin \& Chui, 2009). Looking at the other works done in examining the effect of prior information on listening comprehension, we see somewhat different results. While the findings of the studies highlighted the role of prior information in listening tasks, there are other studies whose findings delimit the effectiveness of such information (Chang \& Read, 2007; Jensen \& Hansen, 1995). Chang and Read (2007) investigated the effect of different types of supports on language learners. They found that the provision of written general information providing general information on content of listening texts in learners' native language increased their listening comprehension in a limited degree. Jensen and Hansen (1995) looked at whether prior study of a lecture topic enhanced performance on the lecture subtests of a content-based listening with underlying thought on the efficacy of prior knowledge on high proficient learners' listening comprehension.

To reach a solid conclusion, this study attempted to shed more light on supporting listening skill and as a result help learners reach an optimal degree of listening comprehension. Building on the previous studies, this study aimed at discovering the extent to which two pre-task activities of glossary of unknown vocabulary items and content related support assisted EFL language learners with their performance on listening comprehension questions across two levels of low and high proficiency.

\section{METHOD}

\section{A. Research Questions and Hypotheses}

RQ1: Are there any differences in the effects of two pre-task activities, glossary of unknown vocabulary items and content related support, on improvement of EFL low proficient learners' listening comprehension?

H01: There are no significant differences in the effects of two pre-task activities, glossary of unknown vocabulary items and content related support, on improvement of EFL low proficient learners, listening comprehension.

H1: There are significant differences in the effects of two pre-task activities, glossary of unknown vocabulary items and content related support, on improvement of EFL low proficient learners, listening comprehension.

RQ2: Are there any differences in the effects of two pre-task activities, glossary of unknown vocabulary items and content related support, on improvement of EFL high proficient learners' listening comprehension?

H02: There are no significant differences in the effects of two pre-task activities, glossary of unknown vocabulary items and content related support, on improvement of EFL high proficient learners' listening comprehension.

$\mathrm{H} 2$ : There are significant differences in the effects of two pre-task activities, glossary of unknown vocabulary items and content related support, on improvement of EFL high proficient learners' listening comprehension.

\section{B. Participants}

A total of 120 language learners with age range of 15-25 participated in this study. 100 female and 20 male participants constituted this population. Before the onset of the study, the participants were divided into two different levels of high and low proficiency by a TOEFL actual test. This led to the formation of three groups, 20 participants in each class, totalling to $60 \mathrm{~L} 2$ learners in each level. The three classes were randomly assigned into two experimental groups and one control group. The experimental groups consisted of vocabulary and content supported groups.

\section{Instruments}

Two language tests were used in the present study to measure language learners' proficiency level and listening comprehension. The first testing material was a TOEFL actual test administered in the past by ETS in 2004. This test was used to divide participants into two levels of proficiency. The second test materials were listening tests following 5 listening comprehension multiple-choice questions and a cloze test with 5 blank spaces, resulting 10 listening comprehension questions totally. The materials used for this study prior to taking the tests were chosen from among recorded lectures appropriate for the levels of participants. The pre-task activity of vocabulary was offered one session before conducting listening tests, whereas written content related support was given only 10 minutes before the test.

\section{Procedures}

Before the onset of the study, the participants were divided into two different levels of high and low proficiency by a TOEFL test. There remained 60 participants in each level making three classes, 20 participants in each class. The three classes were randomly assigned into two experimental groups and one control group. A pre-test of listening comprehension was conducted to guarantee the homogeneity of participants in their listening skill and measure their listening proficiency. 
One experimental group in each level was given a glossary of unknown vocabulary items with the pronunciations as a type of pre-task activity. To make them familiar with the pronunciations and relate the vocabularies to listening text, the glossary was given one session before taking the listening test. Similarly, the other group received written information about the content of forthcoming listening piece. This type of pre-task activity was given just 10 minutes before taking the tests. This pre-task activity was aimed to activate the listeners' pre-existing knowledge and offer a general view about the forthcoming data. It was taken care not to give detailed information in these summaries.

At the beginning, the participants were required to listen once before receiving the questions. The second time along with listening to the task, they were required to answer the questions. At the end, Due to their exposure two times to the listening task, they were asked to fill in the blanks in cloze test without listening to the lecture. To prevent the learners from being aware of the listening text, the students were required to answer the multiple questions at the beginning and then to answer the cloze test.

\section{RESULTS}

\section{A. Testing the First Hypothesis}

To represent comprehensive information about the quantitative analysis of obtained data, the means and standard deviations for the post-test of low proficient learners in each of the three groups are shown in Table 1. The results indicated that there are significant differences between the three groups' post-test mean scores after providing the pretask activities. Especially, the difference between the mean scores of vocabulary group and the other groups, content and control, is higher than between content and control groups.

TABLE 1:

\begin{tabular}{|c|c|c|c|}
\hline \multirow{3}{*}{ Groups } & \multirow{3}{*}{$\mathrm{N}$} & \multirow{2}{*}{\multicolumn{2}{|c|}{ Post-test }} \\
\hline & & & \\
\hline & & $\mathrm{M}$ & SD \\
\hline Vocabulary & 20 & 37.75 & 3.65 \\
\hline Content & 20 & 28.30 & 2.51 \\
\hline Control & 20 & 26.45 & 1.66 \\
\hline
\end{tabular}

In order to find out whether there are statistically significant differences in the effects of pre-task activities on the learners' performance in three groups, the post-test scores were submitted to a one-way ANOVA analysis with between-group factor. The results $(p=.029, \alpha=0.05, p<\alpha)$ illustrated that the difference between the performance of three groups is statistically significant. In other words, the pre-task activities, especially vocabulary items, had a supportive role on LP learners' listening comprehension. So, the first null hypothesis is rejected and the alternative hypothesis is confirmed. To illuminate where the significant differences exist among the groups, Tukey's post hoc test (with an alpha level of .05) was conducted. The results revealed that only vocabulary group outperformed the other two groups. It can be concluded that only the pre-task of vocabulary had a significant and meaningful effect on LP participants' listening comprehension. The results are shown in Table 2 .

TABLE 2:

COMPARING LP LEARNERS' POST-TEST MEAN SCORES

\begin{tabular}{|l|l|l|l|l|l|}
\hline & ANOVA & F & Sig. \\
\hline Between Groups & Sum of Squares & df & Mean Square & 98.100 & .029 \\
\hline Within Groups & 1469.433 & 2 & 734.717 & & \\
\hline Total & $426 . .900$ & 57 & 7.489 & & \\
\hline
\end{tabular}

\section{B. Testing the Second Hypothesis}

The mean scores and standard deviations for post-test of high proficient learners in each of the three groups are represented in Table 3. The results indicated that there are significant differences between the performances of three groups. This means that post-test mean scores of content and vocabulary groups are higher than control group. It shows that provision of pre-task activities enhanced HP learners' listening comprehension in answering post-lecture questions. Especially, the group provided by content related support outscored in listening post-test.

TABLE 3:

DESCRIPTIVE STATISTICS FOR HP LEARNERS' LISTENING COMPREHENSION TESTS

\begin{tabular}{|l|l|l|l|}
\hline \multirow{2}{*}{ Groups } & $\mathrm{N}$ & Post-test & SD \\
\cline { 3 - 4 } & & $\mathrm{M}$ & 3.11 \\
\hline Vocabulary & 20 & 32.55 & 2.59 \\
\hline Content & 20 & 41.75 & 2.23 \\
\hline Control & 20 & 25.60 & \\
\hline
\end{tabular}

Similar to procedure of finding out the significant difference among the three groups for low proficiency level, a oneway ANOVA analysis with between-group factor was conducted for high proficient level. The results indicated that the 
computed $p$ value (.000) is less than the level of significance set in this analysis $(p=0.000, \alpha=0.05, p<\alpha)$. Therefore, this difference is statistically significant, and the second null hypothesis is also rejected and consequently the second alternative hypothesis is accepted. This means that offered pre-task activities for listening tasks improved HP learners' listening performance. To find out exactly which group is supported better by the pre-task activities, Tukey's post hoc test (with an alpha level of .05) was computed. The results showed that both content and vocabulary groups performed better than control group. Despite the effects both pre-task activities had on this level, content related support outperformed vocabulary group. Table 4 illustrates the differences in performances among the groups of HP level.

TABLE 4:

COMPARING HP LEARNERS' POST-TEST MEAN SCORES ANOVA

\begin{tabular}{|l|l|l|l|l|l|}
\hline & Sum of Squares & df & Mean Square & F & Sig. \\
\hline Between Groups & 2625.100 & 2 & 1312.550 & 183.596 & .000 \\
\hline Within Groups & 407.500 & 57 & 7.149 & & \\
\hline Total & 3032.600 & 59 & & & \\
\hline
\end{tabular}

As it is clear from the performance of groups in two levels, it can be concluded that pre-task activities had different supportive roles on low and high proficient learners' performance. In other words, low proficient learners benefited from glossary of unknown vocabulary items in answering post-lecture listening con comprehension questions, whereas high proficient learners' used content related support to answer the listening tests. So, the lack of similarities between two proficiency levels in terms of the effect pre-task activities had on learners' answering post-lecture listening comprehension questions, justifies existence of differences in the effects of pre-task activities on two proficiency levels. This means, comparing the roles of pre-tasks brought out differences in the performance enhancement in two levels. The conclusions are shown in Figure 1 below.

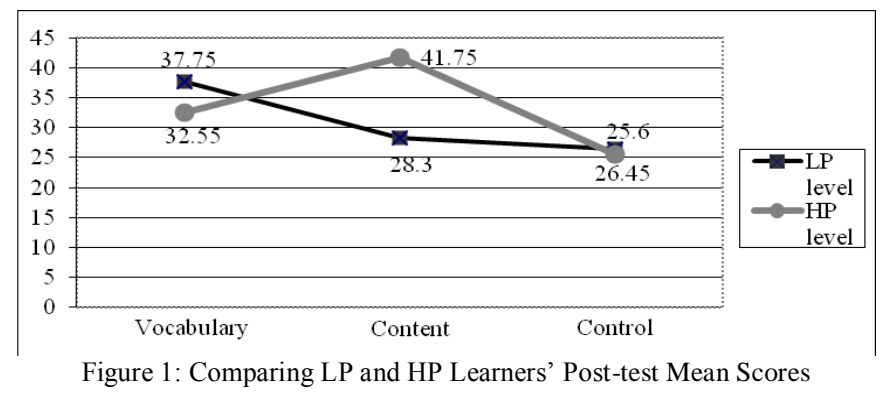

\section{DisCUSSION AND CONCLUSIONS}

The first research question addressed the effects of two pre-task activities on low proficiency level. The results obtained by applying the two pre-task activities indicated that only vocabulary provision enhanced LP learners' listening performance. Related to factors influential in listening comprehension, lack of enough vocabulary knowledge is considered one of the most important ones (Chang, 2005; Chang \& Read, 2006). This has also been pointed out by Ur (1984) who has maintained that failure in relating the linguistic knowledge (vocabularies) to the context and failure in using strategies to summarize the text in macro-level and micro-level can be an important factor in listening comprehension. Also, Boyle (1984) identifies lexical and syntactical knowledge as the most crucial factors contributed to listening process.

According to what is mentioned about the effective role of vocabulary support in bottom-up processing, the finding of this study is in line with studies supporting the low proficient learners' vocabulary use (Lin \& Chui, 2009; Osada, 2001; Tsui \& Fullilove, 1998; Vandergrift, 2003). Additionally, extra preparation time offered to the vocabulary group might be another factor affecting listeners' listening comprehension. Time factor had a crucial role in helping the learner process and internalize the lexical items during the offered time. The findings related to high proficient learners are discussed answering the next research question.

The second research questions concerned the effects of so-called pre-task activities on high proficiency level. The results of offering pre-task activities indicated that content related support enhanced the learners' listening comprehension more than vocabulary items. The factor influential in helping HP learners' use of content related support with background knowledge might be related to their use of specific source activation. In other words, high proficient learners could benefit from the provided content to infer meaning and guess what was in the forthcoming data. In relation to listener's use of schematic knowledge in listening comprehension, conclusion the researches have reached confirms the crucial role it has on listening comprehension (Long, 1989; Markham \& Latham, 1987; Mueller, 1980; Schmidt-Rinehart, 1994; Weissenreider, 1987). Additionally, The finding of this study is sharp contrast with Jensen and Hansen (1995) who concluded that prior knowledge does not support effectively high proficient learners' listening comprehension. 
All these findings, confirm the significant effect of background knowledge on learners' listening comprehension performance. Here, the results of the study are in line with these findings. The findings of this study justified the existence of differences in the performances of learners in two proficiency levels. The glossary of unknown vocabularies in LP level and content related support in HP level, improved learners' listening comprehension. Therefore, differences have been found in supportive roles of pre-task activities across two different proficiency levels.

\section{IMPLICATIONS OF THE STUDY}

Language teachers and syllabus writers are supposed to incorporate a range of pre-listening activities and change the weight of listening lessons from testing listening into teaching listening so that they could support language learners to enhance their listening performance. Listening skill being one of the problematic areas of learning has been focal centre of attention for some researchers recently. To improve this skill the existence of pre-task activities has been emphasized. The most important implication of the current study for the language classes has to do with the type of pre-task activities employed in classrooms to support learners' performance.

\section{REFERENCES}

[1] Anderson, A., \& Lynch, T. (1988). Listening. New York: Oxford University Press.

[2] Brown, G., \& Yule, G. (1983). Teaching the spoken language. Cambridge: Cambridge University Press.

[3] Brown, H. D. (1980). Principles of language learning and teaching. Englewood Cliff, NJ: Prentice Hall.

[4] Boyle, J. (1984). Factors affecting listening comprehension. ELT Journal, 38, 34-38. doi: 10.1093/elt/38.1.34, http://dx.doi.org/10.1093/elt/38.1.34 (accessed 2/10/2010).

[5] Chang, A. C. (2007). The impact of vocabulary preparation on L2 listening comprehension, confidence and strategy use. System, 35, 534- 550. doi: 10.1016/j.system.2007.06.003, http://dx.doi.org/10.1016/j.system.2007.06.003(accessed 20/11/2010).

[6] Chang, A. C., \& Read J. (2007). Support for foreign language listeners: Its effectiveness and limitations. RELC, 38(3), 375- 95. doi: 10.1177/0033688207085853, http://dx.doi.org/10.1177/0033688207085853 (accessed 15/8/2011).

[7] Chang, A. C., \& Read, J. (2008). Reducing listening test anxiety through various forms of listening support. Teaching English as a Second Language, 12, (1), 1-25.

[8] Chastain, K. (1988). Developing second-language skills: Theory and practice (3 $3^{\text {rd }}$ ed.). New York: Harcourt Brace Jovanovich.

[9] Chiang, C. C., \& Dunkel, P. (1992). The effect of speech modification, prior knowledge and listening proficiency on EFL lecture learning. TESOL Quarterly, 26, 345-374. http://dx.doi.org/10.2307/3587009(accessed 26/5/2010).

[10] Donaldson- Evans, M. (1981). Auditory comprehension in the foreign conversation class. The Modern Language Journal, 65, 166-73. doi: 10.2307/325595, http://dx.doi.org/10.2307/325595 (accessed 18/6/2011).

[11] Edwards, R., \& McDonald, J.L. (1993). Schema Theory and Listening,. In A.D. Wolvin, \& C.G.Coakley, (Ed), Perspectives on listening (pp. 60-77). The United States: Ablex Publishing Corporation.

[12] Goh, C. (2000). A cognitive perspective on language learners? listening comprehension problems. System, 28, 55-75. doi: 10.1016/S0346-251X(99)00060-3, http://dx.doi.org/10.1016/S0346-251X(99)00060-3 (accessed 6/12/2011).

[13] Jensen, C., \& Hansen, C. (1995). The effect of prior knowledge on EAP listening-test performance. Language Testing. 12 (1), 99-119.

[14] Kelly, P. (1991). Lexical ignorance: The main obstacle to listening comprehension with advanced foreign language learners. International Review of Applied Linguistics in Language Teaching, 29(2), 135-149.

[15] Keshavarz, M. H., \& Babai, E. (2001). Incompatibility of schema with input in listening comprehension. Indian Journal of Applied Linguistics, 27 (1), 57- 83.

[16] Lin, M., \& Chiu, T. (2009). The impact of an online explicit online lexical program on EFL vocabulary gains and listening comprehension. The Jaltcall Journal, 5. Retrieved from http://jaltcall.org/journal/articles/5_2_Lin.pdf (accessed 5/10/2011).

[17] Long, D. R. (1989). Second language listening comprehension: A schema-theoric perspective. The Modern Language Journal, 73, 32-40. Doi: 10.2307/327265, http://dx.doi.org/10.2307/327265 (accessed 25/4/2011).

[18] Markham, P., \& Latham, M.L. (1987). The influence of religion-specific background knowledge on the listening comprehension of adult second-language students. Language Learning, 37, 157-170.

[19] Mecartty, F. H. (2000). Lexical and grammatical knowledge in reading and listening comprehension by foreign language learners of Spanish. Applied Language Learning, 11(2), 323-348.

[20] Morley, J. (1991). Listening comprehension in second/foreign language instruction. In M. Celce-Murcia (Ed.), Teaching English as a second or foreign language (pp. 81-106). Boston, MA: Heinle \& Heinle.

[21] Mueller, G. (1980). Visual contextual cues and listening comprehension: An experiment. The Modern Language Journal, 64, 335-340. doi: 10.2307/324500, http://dx.doi.org/10.2307/324500 (accessed 20/12/2010).

[22] Osada, N. (2004). Listening comprehension research: A brief review of the past thirty years. Dialogue, 3. Retrieved from http://www.talk waseda.net/dialogue/no03_2004/2004dialogue03_k4.pdf (accessed 6/5/2010).

[23] Richards, J. C. (1983). Listening comprehension: Approach, design, procedure. TESOL Quarterly, 17, 219-240. doi: 10.2307/3586651, http://dx.doi.org/10.2307/3586651(accessed 22/3/2011).

[24] Richards, J. C. (1990). The language teaching matrix. New York: Cambridge University Press.

[25] Rost, M. (1990). Listening in language learning. London: Longman.

[26] Rost, M. (2001). Listening. In, R. Carter \& D. Nunan, (Eds.) The Cambridge Guide to Teaching English to Speakers of Other Languages. Cambridge: Cambridge University.

[27] Schmidt-Rinehart, B. C. (1994). The effects of topic familiarity on second language listening comprehension. The Modern Language Journal, 78, 179-188. doi: 10.2307/329008, http://dx.doi.org/10.2307/329008 (accessed 20/4/2011). 
[28] Taylor, S.E., \& Crocker, J. (1981). Schematic bases of social information processing. In E.T. Higgins, C.P. Herman \& M.P. Zanna (Eds.), Social cognition: The Ontario Symposium (pp. 89-134). Hillslade, NJ: Lawrence Erlbaum.

[29] Tsui, A., \& Fullilove, J. (1998). Bottom-up or top-down processing as a discriminator of L2 listening performance. Applied Linguistics, 19, 432-451. doi: 10.1093/applin/19.4.432, http://dx.doi.org/10.1093/applin/19.4.432 (accessed 5/5/2010).

[30] Underwood, M. (1989). Teaching Listening. London: Longman.

[31] Ur, P. (1984). Teaching listening comprehension. Cambridge: Cambridge University Press.

[32] Vandergrift, L. (2003). Listening: theory and practice in modern foreign language competence. Retrieved from http://www.llas.ac.uk/resources/gpg/67 (accessed 20/3/2010).

[33] Weissenreider, M. (1987). Listening to news in Spanish. Modern Language Learning, 71, 18-27.

[34] Widdowson, H. G. (1983). Learning purposes and language use. Oxford: Oxford UP.

[35] Yule, G. (2006). The study of language ( $3^{\text {rd }}$ ed.). Cambridge: Cambridge University Press.

Farahman Farrokhi was born in Iran in 1967. He received his Ph.D. degree in English language teaching from University of Leeds, England in 2002. He received his M.A. degree in English language teaching from Tarbiat Modarres University, Tehran, Iran in 1993, and he also got the B.A. degree in English translation from AllamehTabatabaii University, Tehran, Iran in 1990.

$\mathrm{He}$ is Dean of the Faculty of Persian literature \& foreign languages at University of Tabriz, and currently he is an associate professor at the University of Tabriz. From 2004 to 2010, he was the Head of International Relations Office at University of Tabriz. From 1994 to 2004, he was the Director of Faculty Registrar at University of Tabriz. Three of his published research papers are listed below: Farrokhi, F. (2005a). Revisiting the ambiguity of recasts. Journal of Faculty of Letters and Humanities, 195, 61-101. Farrokhi, F. (2005b). A practical step towards combining focus on form and focus on meaning. Journal of Faculty of Letters and Humanities, 198, 99-148. Farrokhi, F., Ansarin, A.A., \& Mohammadnia, Z. (2008). Preemptive focus on form: teachers practices across proficiencies. The Linguistic Journal, 3(2), 7-30.

His research interests include classroom discourse analysis, EFL teachers' perceptions of different feedback types, negative and positive evidence in EFL classroom context, language testing, Task-based teaching, and syllabus design.

Vahideh Modarres was born in Tabriz, Iran in 1984. She received her M.A. degree in English language teaching from Tabriz University, Iran in 2011, and also she received her B.A. degree in Translation from Nabi Akram University, Iran in 2007.

She has been teaching general English in private language institutes in Tabriz from 2007 to date. Her research interests include second language acquisition, task-based language teaching, the different effects of pre-task activity types on EFL learners' listening comprehension, and EFL teachers' perceptions of different pre-task types in language learning skills. 